\title{
Private Management
}

and

\author{
Public Policy
}




\section{Stanford Business Classics}

Stanford Business Classics is an effort to make seminal business books, which are often out-of-print, accessible to a new generation of scholars and practitioners.

\section{Additional Stanford Business Classics}

Organizations and Environments

Howard E. Aldrich

The External Control of Organizations: A Resource Dependence Perspective Jeffrey Pfeffer and Gerald R. Salancik

Organizational Strategy, Structure, and Process

Raymond E. Miles and Charles C. Snow

Formal Organizations: A Comparative Approach

Peter M. Blau and W. Richard Scott 


\section{Private Management and}

Public Policy

\section{THE PRINCIPLE OF PUBLIC RESPONSIBILITY}

Lee E. Preston and James E. Post

Stanford Business Books

An Imprint of Stanford University Press

Stanford, California 


\section{Stanford University Press \\ Stanford, California}

(C) 2013 by the Board of Trustees of the Leland Stanford Junior University. All rights reserved.

This book was previously published by Pearson Education, Inc. (C) 1975

No part of this book may be reproduced or transmitted in any form or by any means, electronic or mechanical, including photocopying and recording, or in any information storage or retrieval system without the prior written permission of Stanford University Press.

Special discounts for bulk quantities of Stanford Business Books are available to corporations, professional associations, and other organizations. For details and discount information, contact the special sales department of Stanford University Press. Tel: (650) 736-1782, Fax: (650) 736-1784

Printed in the United States of America on acid-free, archival-quality paper

\section{Library of Congress Cataloging-in-Publication Data}

Preston, Lee E., author.

Private management and public policy : the principle of public responsibility / Lee E. Preston and James E. Post.

$$
\text { pages } \mathrm{cm}
$$

Originally published: Englewood Cliffs, N.J. : Prentice-Hall, [1975]

Includes bibliographical references and index.

ISBN 978-0-8047-8386-6 (pbk. : alk. paper)

1. Industries-Social aspects. 2. Industries-Social aspects-United States. 3. Social responsibility of business. 4. Social responsibility of business-United States. I. Post, James E., author. II. Title.

HD60.P748 2012

$658.4^{\prime} 08-\mathrm{dc} 23$ 
Dedication to the Classic Edition

To the memory

of

LEE E. PRESTON

Dedication to the Original Edition

To the memory

of

ELI GOLDSTON 
